Огляди літератури, оригінальні дослідження, погляд на проблему, випадок з практики, короткі повідомлення УДК 616.12-005.4-06:616.12-008.331.1]-008.9/-009-07

DOI 10.11603/1811-2471.2019.v.i3.10439

\title{
МЕТАБОЛІЧНІ, ПСИХОВЕГЕТАТИВНІ ПОРУШЕННЯ ТА ЯКІСТЬ ЖИТТЯ ХВОРИХ НА ІШЕМІЧНУ ХВОРОБУ СЕРЦЯ ТА АРТЕРІАЛЬНУ ГІПЕРТЕНЗІЮ
}

\author{
○Н. С. Михайловська, С. М. Мануйлов, Г. В. Грицай \\ Запорізький державний медичний університет
}

РЕЗЮМЕ. На сьогодні наявність супутніх метаболічних та психовегетативних порушень $є$ доведеним фактором ризику погіршення соматичного стану хворих на ішемічну хворобу серця (IXC) та артеріальну гіпертензію (АГ), а також предиктором зниження якості життя пацієнтів.

Мета - вивчити особливості метаболічних, психовегетативних розладів та їх вплив на якість життя хворих на IXC, коморбідну з АГ.

Матеріал і методи.У проспективне моноцентрове подвійне відкрите дослідження з елементами рандомізації в паралельних групах залучено 56 хворих на IXC: стабільну стенокардію напруження II-III функціональних класів, коморбідну з АГ (медіана віку 59,0 (54,0; 65,0) років). Хворі були поділені на дві групи: 1 група - 34 хворих на IXC у поєднанні з тривожно-депресивними розладами (ТДР), 2 група - 22 пацієнти без ТДР. Дослідження якості життя у хворих на IXC проводили за допомогою Сіетлівського опитувальника (SAQ) та опитувальника SF-36; виявлення ТДР - за допомогою Госпітальної шкали тривоги і депресії HADS; оцінку вегетативної дисфункції - за допомогою визначення часових і спектральних параметрів варіабельності серцевого ритму (ВСР).

Результати. У хворих на IXC та АГ з ТДР відмічали більш виражені прояви метаболічного синдрому (ступінь ожиріння, атерогенна дисліпідемія, гіперглікемія), які мали прямий кореляційний взаємозв'язок з сумарним рівнем тривоги і депресії. У хворих на IXC та АГ з ТДР протягом доби частіше реєструвалися шлуночкові екстрасистоли, виявлена значно довша загальна тривалість депресії сегмента ST (на 22,5 \%) (p<0,05) та більш глибока депресія сегмента ST (у 2,14 раза) (р<0,05), порівняно з хворими без ТДР, вегетативний дисбаланс зі зниженням загальної варіабельності серцевого ритму, переважанням активності симпатичної ланки на тлі пригнічення парасимпатичних впливів. У хворих на IXC з АГ з ТДР виявлено погіршення якості життя за даними Сіетлівського опитувальника та загального опитувальника здоров'я SF-36.

Висновки. Наявність тривожно-депресивних розладів у хворих на IXC з АГ супроводжується більш вираженими метаболічними, ішемічними порушеннями, вегетативним дисбалансом та зниженням якості життя.

ключовІ словА: ішемічна хвороба серця; артеріальна гіпертензія; метаболічні та психовегетативні порушення; якість життя.

Вступ. Артеріальна гіпертензія (АГ) $є$ незалежним фактором ризику серцево-судинних та цереброваскулярних захворювань, тому залишається однією з актуальних проблем сучасної медицини [1, 2]. АГ пов'язана з підвищеним ризиком розвитку ішемічної хвороби серця (IXC) та часто 3 нею поєднується [1]. Питома вага IXC у структурі серцево-судинних захворювань в Україні складає $27,5 \%$, АГ - 41,2 \%, причому за 20 років поширеність цих хвороб зросла в 3,3 та 3,6 раза відповідно [2]. Тому актуальним $є$ вивчення факторів, які впливають на прогноз і ефективність лікування IXC, в тому числі психічних розладів тривожнодепресивного спектра, які зустрічаються у $20 \%$ пацієнтів з IXC та у 45,6 \% хворих на АГ $[1,3]$.

Тривожно-депресивні розлади (ТДР) $\epsilon$ не лише психологічною реакцією на соматичне порушення, а й важливою ланкою у каскаді біохімічних реакцій, що супроводжують цей стан [6]. При тривалій депресії виявляються ознаки гіперреактивності гіпоталамо-гіпофізарно-наднирковозалозної системи з посиленням вироблення кортизолу, а також збільшення кількості нейронів, які секретують кортикотропін-рилізинг фактор. Хронічна гіперкортизолемія призводить до форму- вання інсулінорезистентності, гіперглікемії та сприяє підвищенню рівня контрінсулярних гормонів. Поєднання цих факторів стає тригером для розвитку ускладнень при IXC та АГ, що проявляються у метаболічних, вегетативних та психоемоційних розладах, які потребують медикаментозної корекції під час лікування основного захворювання [9].

Існуючі стандарти не передбачають рекомендацій з виявлення супутніх психовегетативних розладів у хворих на IXC з АГ [10]. Наслідком відсутності їх своєчасного виявлення та адекватного лікування $\epsilon$ підвищення ризику інвалідизації та смертності хворих, погіршення якості життя та соціального функціонування $[10,11]$. Метаболічні, психовегетативні порушення у хворих на IXC з АГ вивчені недостатньо, що обґрунтовує доцільність проведення даного наукового дослідження.

Мета - вивчити особливості метаболічних, психовегетативних розладів у хворих на IXC, коморбідну з АГ, та їх вплив на якість життя цих пацієнтів.

Матеріал і методи дослідження. У проспективне моноцентрове подвійне відкрите дослідження з елементами рандомізації в паралельних групах залучено 56 хворих на IXC: стабільну 
Огляди літератури, оригінальні дослідження, погляд на проблему, випадок з практики, короткі повідомлення стенокардію напруження II-III функціональних класів, коморбідну з АГ, віком від 42 до 68 років (медіана віку - 59,0 (54,0; 65,0) років; 26 жінок, 30 чоловіків). Хворі були поділені наступним чином: 1 група - 34 хворих на IXC у поєднанні з ТДР і 2 група - 22 пацієнти без ТДР.

Діагноз ГХ, ІХC та функціонального класу стабільної стенокардії ґрунтувався на комплексному аналізі скарг, даних фізикального обстеження, результатах лабораторних та інструментальних досліджень згідно з Національними стандартами (Накази МО3 України: від 03.07.2006 р. № 436; від 02.03.2016 р. № 152 зі змінами від 23.09.2016 р. № 994; від 24.05.2012 р. № 384). Компоненти метаболічного синдрому у хворих на IXC визначали за критеріями IDF (2009 р.).

Критерії включення в дослідження: інформована згода пацієнта, наявність верифікованої IXC, АГ та МС. Критерії виключення: декомпенсована серцева недостатність; гострий коронарний синдром або гостре порушення мозкового кровообігу менш ніж за 3 місяці до початку дослідження; соматична патологія в стадії декомпенсації; вроджені або набуті вади серця; психічні захворювання; системна, онкологічна, аутоімунна патологія.

Усім хворим проводили комплексне клінічне обстеження з урахуванням скарг, даних анамнезу, об'єктивних, лабораторних та інструментальних методів дослідження згідно із загальноприйнятими стандартами. Антропометричне дослідження включало вимірювання обводу талії (ОТ) та стегон (ОС), також визначення їх співвідношення (ОТ/OC). Вимірювали зріст хворого (см) та масу тіла (кг) з наступним розрахунком індексу маси тіла (індекс Кетле) за формулою: IMT = маса тіла (в кг) / зріст (в м²), де показник ІМТ від 18,5 до 24,9 відповідає нормальному діапазону.

Рівні глюкози, загального холестерину (3ХC), ліпопротеїдів високої щільності, тригліцеридів визначали з використанням набору реактивів BIOLATEST компанії PLIVA-Lachema (Чеська республіка) за загальноприйнятою методикою. Рівень холестерину ліпопротеїдів низької щільності (ХС лПНЩ) розраховували за формулою Friedewald (1972).

Дослідження якості життя у хворих на IXC проводили за допомогою Сіетлівського опитувальника (SAQ) та опитувальника SF-36. Виявлення ТДР здійснювали за допомогою Госпітальної шкали тривоги і депресії HADS (Hospital Anxiety and Depression Scale).

Оцінку вегетативної дисфункції здійснювали шляхом оцінки часових і спектральних показників варіабельності серцевого ритму (ВСР). Добове моніторування ЕКГ проводили за допомогою портативної системи Кардіосенс К (м. Харків). При аналізі ВСР використовували часові і спектральні параметри, рекомендовані Комітетом експертів Північноамериканського товариства стимуляції та електрофізіології, Європейського товариства кардіологів і Української асоціації кардіологів.

Статистичну обробку даних проводили із застосуванням пакета ліцензійної програми «Statistica 13.0»(StatSoftInc,CШA,№JPZ8041382130ARCN10-J). Гіпотезу про нормальність розподілу досліджуваних показників перевіряли з використанням критерію Шапіро-Уїлка. Кількісні ознаки були представлені у вигляді $\mathrm{M} \pm \mathrm{m}$ (середнє арифметичне \pm стандартна похибка середнього арифметичного) а6о Ме (Q25; Q75) (медіана, 25 і 75 перцентіль) залежно від виду розподілу. При нормальному розподілі достовірність відмінностей оцінювали за допомогою t-критерію Стьюдента для незалежних та залежних вибірок. При розподілі, що відрізняється від нормального, використовували непараметричні критерії: U-критерій Манна-Уїтні для незалежних вибірок і критерій Вілкоксона для залежних вибірок. Для оцінки взаємозв'язків між показниками використовували метод кореляційного аналізу з обчисленням коефіцієнтів кореляції Пірсона (при нормальному розподілі) i Спірмена (при розподілі, що відрізняється від нормального).

Результати й обговорення. Особливості метаболічних порушень у хворих на IXC з АГ залежно від наявності ТДР наведені в таблиці 1.

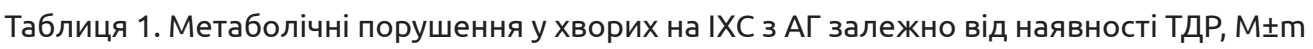

\begin{tabular}{|l|c|c|}
\hline \multicolumn{1}{|c|}{ Показник } & 1 група $(\mathrm{n}=34)$ & 2 група $(\mathrm{n}=22)$ \\
\hline $\mathrm{IMT}, \mathrm{кг} / \mathrm{M}^{2}$ & $32,7 \pm 3,14^{*}$ & $27,7 \pm 4,8$ \\
\hline ОТ, см & $105,2 \pm 7,55^{*}$ & $95,9 \pm 7,44$ \\
\hline Глюкоза, ммоль/л & $6,9 \pm 3,8^{*}$ & $6,1 \pm 3,4$ \\
\hline САТ, мм рт. ст. & $151,5 \pm 18,84$ & $150,8 \pm 4,91$ \\
\hline ЗХС, ммоль/л & $6,2 \pm 1,88^{*}$ & $5,2 \pm 1,4$ \\
\hline ТГ, ммоль/л & $2,4 \pm 1,47^{*}$ & $1,9 \pm 0,8$ \\
\hline ЛПНЩ, ммоль/л & $4,0 \pm 1,87$ & $3,2 \pm 1,61$ \\
\hline ЛПВЩ, ммоль/л & $1,1 \pm 0,42$ & $2,1 \pm 1,34$ \\
\hline
\end{tabular}

Примітка. * - вірогідність відмінностей між групами $(p<0,05)$. 
Огляди літератури, оригінальні дослідження, погляд на проблему, випадок з практики, короткі повідомлення

Встановлено, що у хворих на IXC та АГ з ТДР IMT був достовірно вищим на $16 \%$, ОТ на $9 \%$, рівень глюкози на $12 \%$, загального холестерину на 16 \%, тригліцеридів на $21 \%(p<0,05)$, спостерігалася тенденція до підвищення лПнщ і зменшення рівня ЛПВЩ. Виявлено позитивний кореляційний взаємозв'язок середньої сили між сумарним рівнем тривоги і депресії та рівнем 3XC ( $r=+0,43$; $p<0,05)$, тригліцеридів $(r=+0,40 ; p<0,05)$, глюкози крові $(r=+0,55 ; p<0,05)$, ІМТ $(r=+0,50 ; p<0,05)$, ОТ $(r=+0,45 ; p<0,05)$.

За даними Сіетлівського опитувальника, в групі хворих з ТДР спостерігалося більш виражене обмеження фізичної активності на 6,7 \%, збільшення частоти нападів стенокардії на 17,5 \%, зниження задоволеності лікуванням на 20,1% (р<0,05) (та6л. 2).

Таблиця 2. Якість життя хворих на IXC з АГ залежно від наявності ТДР за даними Сіетлівського опитувальника, $\mathrm{M \pm m}$

\begin{tabular}{|l|c|c|}
\hline \multicolumn{1}{|c|}{ Показник } & 1 група (n=34) & 2 група (n=22) \\
\hline Обмеження фізичної активності (PL), \% & $28,90 \pm 3,51^{*}$ & $35,56 \pm 4,10$ \\
\hline Стабільність нападів стенокардії (AS), \% & $75,00 \pm 7,50$ & $76,08 \pm 7,90$ \\
\hline Частота нападів стенокардії (AF), \% & $40,00 \pm 9,49 *$ & $57,50 \pm 8,54$ \\
\hline Задоволеність лікуванням (TS), \% & $65,32 \pm 3,62 *$ & $85,50 \pm 0,79$ \\
\hline Відношення до захворювання (DP), \% & $56,69 \pm 4,30$ & $58,30 \pm 4,50$ \\
\hline
\end{tabular}

Примітка: * - вірогідність відмінностей між групами $(p<0,05)$.

Встановлений прямий кореляційний взаємозв'язок середньої сили між сумарним рівнем тривоги і депресії з PL $(r=+0,44 ; p<0,05), \mathrm{AF}$ $(r=+0,45 ; p<0,05), D R(r=-0,40 ; p<0,05)$, що підтверджує вплив ТДР на перебіг IXC, коморбідну з МС.

Оцінка якості життя з використанням загального опитувальника здоров'я SF-36 за 8 концепці- ями здоров'я продемонструвала схильність хворих з ТДР до більш низьких середньогрупових значень за наступними шкалами: фізичне функціонування, рольове емоційне функціонування, психічне здоров'я і соціальне функціонування, що свідчить про вплив ТДР на якість життя цих хворих (рис. 1).

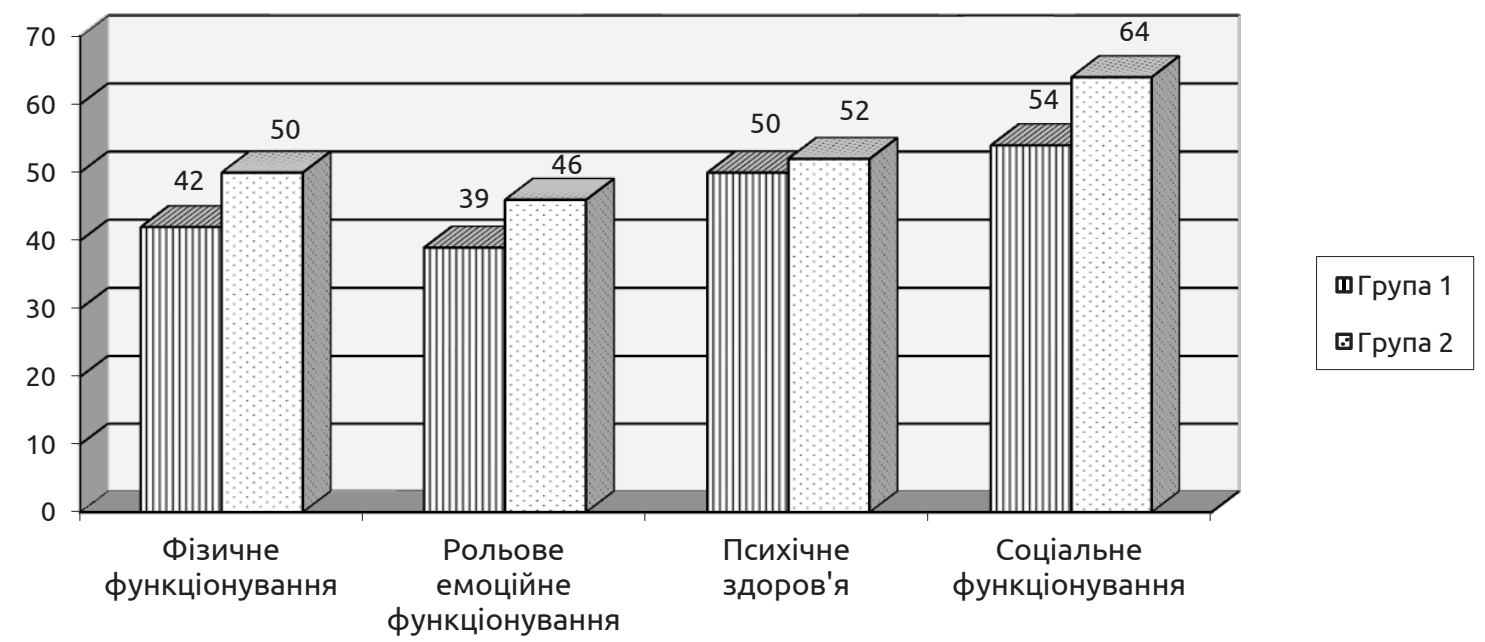

Рис. 1. Якість життя хворих залежно від наявності ТДР за даними опитувальника SF-36.

Таким чином, в групі хворих на IXC та АГ з ТДР відмічаються більш виражені прояви метаболічного синдрому (ступінь ожиріння, атерогенна дисліпідемія, гіперглікемія), які мають кореляційний взаємозв'язок з сумарним рівнем тривоги і депресії. Наявність тривожно-депресивних розладів у хворих на IXC з АГ супроводжується погіршенням якості життя за даними Сіетлівського опитувальника та загального опитувальника здоров'я SF-36.

Показники добового моніторування ЕКГ у хворих на IXC з АГ в залежності від наявності ТДР представлені в таблиці 3.

При аналізі даних добового моніторування ЕКГ у хворих на IXC з АГ у поєднанні з ТДР спосте- 
Огляди літератури, оригінальні дослідження, погляд на проблему, випадок з практики, короткі повідомлення Таблиця 3. Показники добового моніторування ЕКГ у хворих на IXC з АГ залежно від наявності TДP, Mе $\left(Q_{25} ; Q_{75}\right)$

\begin{tabular}{|c|c|c|}
\hline Показник & 1 група $(n=34)$ & 2 група (n=22) \\
\hline Середня ЧСС увесь період, уд. за хв & $\begin{array}{c}71 \\
(64 ; 77) \\
\end{array}$ & $\begin{array}{c}65 \\
(60 ; 74) \\
\end{array}$ \\
\hline Середня ЧСС за день, уд. за хв & $\begin{array}{c}75 \\
(67 ; 83)^{*}\end{array}$ & $\begin{array}{c}67 \\
(62 ; 79)\end{array}$ \\
\hline Середня ЧСС вночі, уд. за хв & $\begin{array}{c}64 \\
(56 ; 69)\end{array}$ & $\begin{array}{c}60 \\
(60 ; 64)\end{array}$ \\
\hline Мінімальна ЧСС увесь період, уд. за хв & $\begin{array}{c}54 \\
(45 ; 55)\end{array}$ & $\begin{array}{c}49 \\
(45 ; 48)\end{array}$ \\
\hline Максимальна ЧСС увесь період, уд. за хв & $\begin{array}{c}114 \\
(97 ; 126) \\
\end{array}$ & $\begin{array}{c}123 \\
(98 ; 142) \\
\end{array}$ \\
\hline Кількість епізодів тахікардії, еп./доб. & $\begin{array}{c}28 \\
(3 ; 110) \\
\end{array}$ & $\begin{array}{c}12 \\
(3 ; 157) \\
\end{array}$ \\
\hline Шлуночкова екстрасистолія, еп./доб. & $\begin{array}{c}99 \\
(19 ; 290) *\end{array}$ & $\begin{array}{c}13 \\
(4 ; 225)\end{array}$ \\
\hline Надшлуночкова екстрасистолія, еп./доб. & $\begin{array}{c}124 \\
(13 ; 259)\end{array}$ & $\begin{array}{c}164 \\
(62 ; 199)\end{array}$ \\
\hline Тривалість депресії ST, хв/доб. & $\begin{array}{c}13,5 \\
(7,7 ; 23,0) \text { * }\end{array}$ & $\begin{array}{c}11,0 \\
(7,0 ; 16,0)\end{array}$ \\
\hline Глибина депресії сегмента ST, мкB & $\begin{array}{c}184,0 \\
(140,0 ; 235,0)^{*}\end{array}$ & $\begin{array}{c}85,7 \\
(4,5 ; 167,0) \\
\end{array}$ \\
\hline
\end{tabular}

Примітка. * - вірогідність різниці показників між групами хворих $(p<0,05)$.

рігали більшу середню ЧСС у денний період $(p<0,05)$, порівняно з групою зіставлення. За іншими показниками ЧСС групи істотно не відрізнялись. Виявлено тенденцію до збільшення кількості епізодів виникнення синусової тахікардії.

У хворих на IXC та АГ з ТДР протягом доби частіше спостерігали шлуночкові екстрасистоли I-II класу за B. Lown $(p<0,05)$. За частотою реєстрації надшлуночкової екстрасистолії достовірних відмінностей між групами не виявлено. У хворих основної групи реєстрували значно довшу загальну тривалість депресії сегмента ST на $22,5 \%$ $(p<0,05)$ та більш глибоку депресію сегмента ST у 2,14 раза $(p<0,05)$, порівняно з хворими без ТДР.

Показники варіабельності серцевого ритму, за результатами добового моніторування ЕКГ за Холтером, в залежності від наявності ТДР, мали наступні особливості. Порівняльний аналіз часових показників варіабельності серцевого ритму у хво- рих на IXC з АГС та ТДР виявив вірогідне зменшення стандартного відхилення NN інтервалів (SDNNi), що відображає сумарну активність ВСР, на 44 \% в активний та на $61 \%$ в пасивний період $(p<0,05)$. Спектральний аналіз варіабельності серцевого ритму показав вірогідне збільшення LF на 40 \% в активному і на 51 \% в пасивному періодах, поруч із достовірним зменшенням показника HF на 43 \% в активному та на 61 \% у пасивному періодах, що відображає парасимпатичні впливи на серцеву діяльність. Крім того, у хворих на IXС з АГ та ТДР спостерігалось істотне збільшення відношення LF/HF найчутливішого показника вегетативного балансу, на $16 \%$ в активному періоді та на 17 \% в пасивному періоді $(p<0,05)$, що вказує на вегетативний дисбаланс за рахунок переважання симпатичних впливів над парасимпатичними (рис. 2) і підтверджується кореляційним взаємозв'язком зі ступенем вираженості ТДР $(r=+0,55 ; \mathrm{p}<0,05)$.

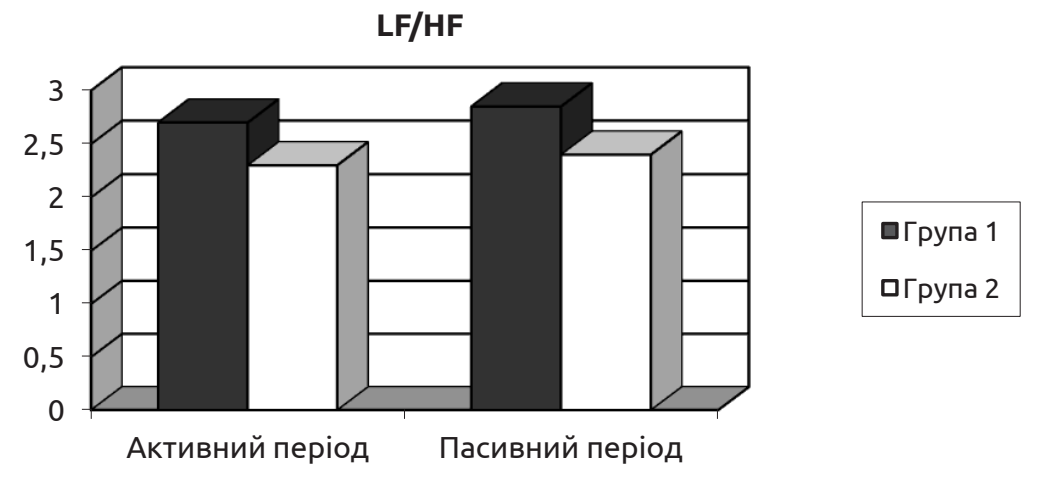

Рис. 2. Особливості симпато-вагального балансу у хворих на IXC з АГ залежно від наявності ТДР. 
Огляди літератури, оригінальні дослідження, погляд на проблему, випадок з практики, короткі повідомлення

Таким чином, у хворих на IXC з АГ, поєднаних з ТДР, спостерігається дисбаланс ВНС зі зниженням загальної варіабельності серцевого ритму, симпато-парасимпатичним дисбалансом з переважанням активності симпатичної ланки на тлі пригнічення парасимпатичних впливів.

Ми встановили взаємозв'язок ТДР з компонентами МС у хворих на IXC. Подібні результати отримані в роботах інших дослідників, зокрема, за даними І. О. Прохоренко і співавт. (2012р.) депресія асоціюється з такими показниками МС, як абдомінальне ожиріння, гіперглікемія, дисліпідемія. Автори пояснюють отримані дані тим, що на тлі ТДР виникає підвищення рівня кортизолу, який стимулює кортизолзалежну ліпопротеїнову ліпазу вісцерального жиру (кортизолзалежна жирова тканина) [4]. Як наслідок розвивається абдомінальне ожиріння, зменшується чутливість тканин до дії інсуліну, посилюється розпад глікогену в печінці, у зв'язку з чим підвищується рівень глюкози в крові та прогресує інсулінорезистентність. Гіперінсулінемія, в свою чергу, індукує атерогенні зміни ліпідного спектра крові $[10,11]$.

У нашому дослідженні ми встановили погіршення якості життя хворих на IXC з МС на тлі ТДР, що збігається з результатами інших дослідників [5, 7-10]. Так, В. В. Калюжин і співавт. (2012 р.) відзначили, що у хворих на IXC з абдомінальним ожирінням, порівняно з пацієнтами з нормальною масою тіла, спостерігають збільшення рівня тривожності, ступеня психосоціальної дезадаптації, частоти кардіалгій, зменшення толерантності до ізометричного навантаження і погіршення якості життя [5]. Результати досліджень інших авторів стверджують, що збільшення маси тіла сприяло клінічній маніфестації тривожних і депресивних розладів у пацієнтів з МС, тим самим погіршуючи якість життя хворих [7-9].

Згідно з результатами загального опитувальника здоров'я SF-36, при наявності ТДР хворі на IXC рідше дотримуються здорового способу життя, гірше виконують лікарські рекомендації щодо дієти, режиму фізичної активності [8]. Наявність тривожно-депресивної симптоматики сприяє зниженню задоволеності лікуванням і, як наслідок, негативно впливає на прихильність хворих до рекомендованої медикаментозної терапії, що сприяє збільшенню частоти нападів стенокардії за даними Сіетлівського опитувальника [10].

Ми виявили зниження ВСР у хворих на IXC та АГ з тривожно-депресивними розладами, що може призвести до незбалансованої симпатичної стимуляції серця і сприяти розвитку шлуночкових аритмій, підвищеної адгезивної активності тромбоцитів і, як наслідок, стати причиною збільшення раптової серцево-судинної смертності даної категорії хворих [9]. Наявність структурної патології серця, дискоординація між еферентними імпульсами 3 центральних структур, нейрогуморальними механізмами вегетативної активності та станом аферентних зв'язків, разом з дисфункцією центральних нервових структур при наявності IXC, АГ та ТДР, створюють умови для розвитку електричної нестабільності серця $[9,10]$.

Висновки. 1. У хворих на IXC та АГ з тривожно-депресивними розладами відмічаються більш виражені прояви метаболічного синдрому (ступінь ожиріння, атерогенна дисліпідемія, гіперглікемія), які мають кореляційний взаємозв'язок 3 сумарним рівнем тривоги і депресії

2. Наявність тривожно-депресивних розладів у хворих на IXC з АГ сприяє погіршенню якості життя пацієнтів за даними Сіетлівського опитувальника та загального опитувальника здоров'я SF-36.

3. Хворим на IXC з АГ, поєднані з тривожно-депресивними розладами, притаманні більш виражені ішемічні зміни міокарда, збільшення частоти реєстрації шлуночкових екстрасистол, дисбаланс вегетативної нервової системи 3 переважанням активності симпатичної ланки на тлі пригнічення парасимпатичних впливів.

Перспективним $\epsilon$ вивчення можливостей фармакологічної корекції виявлених порушень у хворих на IXC з супутньою АГ.

\section{ЛІТЕРАТУРА}

1. Гандзюк В. А. Анализ заболеваемости ишемической болезнью сердца в Украине / В. А. Гандзюк // Укр. кардиол. журн. - 2014. - № 3. - С. 45-52.

2. Лутай М. И. Диагностика и лечение стабильной стенокардии в Украине: проблемы и перспективы / М. И. Лутай, А. Ф. Лысенко, Г. Й. Поликова // Матеріали XIV Національного конгресу кардіологів України, 2013. C.119.

3. Федоришина О. В. Тревога, депрессия и качество жизни у больных артериальной гипертензией трудоспособного возраста / О. В. Федоришина, К. В. Протасов,
С. Г. Куклин // Сибирский медицинский журнал. - 2013. № 121 (6). - С. 58-61.

4. Прохоренко И. О. Влияние депрессии на формирование метаболического синдрома и развитие ИБС у пациентов старших возрастных групп / И. О. Прохоренко, Е. Г. Зарубина, Т. В. Моисеева // Современные проблемы науки и образования. - 2012. - № 6.

5. Качество жизни больных ишемической болезнью сердца, ассоциированной с метаболическим синдромом: результаты факторного анализа / В. В. Калюжин, А. Т. Тепляков, Н. В. Рязанцева [и др.] // Терапевти- 
Огляди літератури, оригінальні дослідження, погляд на проблему, випадок з практики, короткі повідомлення ческий архив. - 2012. - № 12. - С. 20-21.

6. Долженко М. Н. Депрессивные и тревожные расстройства в кардиологии: возможность комбинированной терапии антидепресантом и антигипоксантом / М. Н. Долженко // Новости медицины и фармации. 2013. - №14. - C. 45-46.

7. Risk of anxiety and depressive disorders in patients with myocardial infarction / H. P. Feng, W. C. Chien, W. T. Cheng [et al.] // Medicine (Baltimore). - 2016. - Vol. 95 (34). - P. e4464.

8. Depression increases the onset of cardiovasculardisease over and above other determinants in older primary care patients, a cohort study / H. W. J. van Marwijk, K. G. van der Kooy, C. D. A. Stehouwer [et al.] // BMC Cardiovasc. Disord. - 2015. - Vol. 15, Issue 1. - P. 2-8.

9. Lankarani M. M. Baseline depressive symptoms predict subsequent heart disease; 20-Year Cohort / M. M. Lankarani, S. A. Assari // Int. Cardiovasc. Res. J. 2016. Vol. 10 (1). - P. 29-34.

10. Клиническая эффективность использования L-аргинина у больных ишемической болезнью сердца и метаболическим синдромом / Н. Михайловська, І. Стецюк, Т. Кулинич, О. Лісова // Семейная медицина. 2019. - № 2. - Р. 59-65.

\title{
REFERENCES
}

1. Handzyuk, V.A. (2014). Analiz zabolevayemosti ishemycheskoy boleznyu serdtsa $v$ Ukraine [Analysis of the incidence of coronary heart disease in Ukraine]. Ukr. kardiol. zhurn. - Ukr. Cardiol. Journal, 3, 45-52 [in Russian].

2. Lutay, M.Y., Lysenko, A.F., \& Polykova, H.Y. (2013). Diagnostika i lechenye stabilnoy stenokardii v Ukraine: problemy i perspektivy [Diagnosis and treatment of stable angina pectoris in Ukraine: problems and prospects]. Proceedings of the XIV Natsionalnyi konhres kardiolohiv Ukrainy - XIV National Congress of Cardiology of Ukraine [in Russian].

3. Fedoryshyna, O.V., Protasov, K.V., \& Kuklyn, S.H. (2013). Trevoga, depressiya i kachestvo zhyzni u bolnykh arteryalnoy gipertenzyiyey trudosposobnogo vozrasta [Anxiety, depression and quality of life in patients with working-age arterial hypertension]. Sibirskyy meditsynskiy zhurnal - Siberian Medical Journal, 121 (6), 58-61 [in Russian].

4. Prokhorenko, I.O., Zarubina, E.G., \& Moyseeva, T.V. (2012). Vliyanye depressii na formirovanye metabolicheskogo sindroma i razvitye IBS u patsyentov starshykh vozrastnykh grupp [Influence of depression on the formation of metabolic syndrome and the development of coronary heart disease in patients of older age groups]. Sovremennye problemy nauki i obrazovaniya - Modern Problems of Science and Education, 6 [in Russian].

5. Kalyuzhyn, V.V., Teplyakov, A.T., Ryazantseva, N.V., Bespalova, Y.D., Kamaev, D.Yu., \& Kalyuzhyna E.V. (2012). Kachestvo zhyzni bolnykh ishemycheskoy boleznyu serdtsa, assotsyirovannoy s metabolicheskym sindromom:

rezultaty faktornogo analiza [Quality of life of patients with coronary heart disease associated with metabolic syndrome: results of factor analysis]. Terapevticheskiy arkhiv - Therapeutic Archive, 12, 20-21 [in Russian].

6. Dolzhenko, M.N. (2013). Depressivnye i trevozhnye rasstroystva v kardiologii: vozmozhnost kombinirovannoy terapii antidepresantom i antygipoksantom [Depressive and anxiety disorders in cardiology: the possibility of combination therapy with an antidepressant and antihypoxant]. Novosti meditsyny i farmatsii - News of Medicine and Pharmacy, 14, 45-46 [in Russian].

7. Feng, H.P., Chien, W.C., Cheng, W.T., Chung, C.H., Cheng, S.M., \& Tzeng, W.C. (2016). Risk of anxiety and depressive disorders in patients with myocardial infarction. Medicine (Baltimore), 95 (34), e4464.

8. van Marwijk, H.W., van der Kooy, K.G., Stehouwer, C.D., Beekman, A.T., \& van Hout, H.P. (2015). Depression increases the onset of cardiovasculardisease over and above other determinants in older primary care patients, a cohort study. BMC Cardiovasc Disord., 15, 1, 2-8.

9. Lankarani, M.M., \& Assari, S. (2016). Baseline depressive symptoms predict subsequent heart disease; A 20-Year Cohort. Int. Cardiovasc. Res. J. Vol. 10 (1), 29-34.

10. Mykhaylovska, N., Stetsyuk, I., Kulynych, T., \& Lisova, O. (2019). Klinicheskaya effektivnost ispolzovaniya L-arginina u bolnykh ishemicheskoy boleznyu serdtsa I metabolycheskym sindromom [Clinical effectiveness of the use of L-arginine in patients with coronary heart disease and metabolic syndrome]. Semeynaya meditsyna - Family Medicine, 2, 59-65 [in Russian].

\section{МЕТАБОЛИЧЕСКИЕ, ПСИХОВЕГЕТАТИВНЫЕ НАРУШЕНИЯ И КАЧЕСТВО ЖИЗНИ У БОЛЬНЫХ ИШЕМИЧЕСКОЙ БОЛЕЗНЬЮ СЕРДЦА И АРТЕРИАЛЬНОЙ ГИПЕРТЕНЗИЕЙ}

\author{
๑Н. С. Михайловская, С. Н. Мануйлов, А. В. Грицай \\ Запорожский государственный медицинский университет
}

РЕЗЮМЕ. На сегодня наличие сопутствующих метаболических и психовегетативных нарушений является доказанным фактором риска ухудшения соматического состояния больных ишемической болезнью сердца (ИБС) и артериальной гипертензией (АГ), а также предиктором снижения качества жизни данной категории пациентов.

Цель - изучить особенности метаболических, психовегетативных расстройств и их влияние на качество жизни больных ИБС, коморбидной с АГ.

Материал и методы. В проспективное моноцентрове двойное открытое исследование с элементами рандомизации в параллельных группах привлечено 56 больных ИБС: стабильной стенокардией напряжения II-III функцио- 
Огляди літератури, оригінальні дослідження, погляд на проблему, випадок з практики, короткі повідомлення нального класса, коморбидной с АГ (медиана возраста 59,0 (54,0; 65,0) лет). Больные были поделены на две группы: 1 группа - 34 больных ИБС с АГ в сочетании с тревожно-депрессивными расстройствами (ТДР) и 2 группа - 22 пациента без ТДР. Исследование качества жизни у больных ИБС проводилось с помощью Сиетловського опросника (SAQ) и опросника SF-36; выявление TДP - с помощью Госпитальной шкалы тревоги и депрессии (HADS); оценка вегетативной дисфункции - с помощью определения временных и спектральных параметров вариабельности сердечного ритма (ВСР).

Результаты. У больных ИБС и АГ с ТДР отмечались более выраженные проявления метаболического синдрома (степень ожирения, атерогенная дислипидемия, гипергликемия), которые имели прямую корреляционную взаимосвязь с суммарным уровнем тревоги и депрессии. У больных ИБС и АГ с ТДР в течение суток чаще регистрировались желудочковые экстрасистолы, значительно длиннее общая продолжительность депрессии сегмента ST - на $22,5$ \% ( $<<0,05)$ и более глубокая депрессия сегмента ST - в 2,14 раза $(p<0,05)$ по сравнению с больными без ТДР, вегетативный дисбаланс со снижением общей вариабельности сердечного ритма, преобладанием активности симпатического звена на фоне угнетения парасимпатических влияний. У больных ИБС с АГ с ТДР выявлено ухудшение качества жизни по данным Сиетловського опросника и общего опросника здоровья SF-36.

Выводы. Наличие тревожно-депрессивных расстройств у больных ИБС с АГ сопровождается более выраженными метаболическими, ишемическими нарушениями, вегетативным дисбалансом и снижением качества жизни пациентов.

КЛЮЧЕВЫЕ СЛОВА: ишемическая болезнь сердца; артериальная гипертензия; метаболические и психовегетативные нарушения; качество жизни.

\title{
METABOLIC, PSYCHIC-VEGETATIVE DISORDERS AND QUALITY OF LIFE IN PATIENTS WITH ISCHEMIC HEART DISEASE AND ARTERIAL HYPERTENSION
}

\author{
@N. S. Mykhailovska, S. M. Manuilov, H. V. Grytsai \\ Zaporizhzhia State Medical University
}

SUMMARY. Nowadays, the presence of concomitant metabolic and psycho-autonomic disorders is a proven risk factor for worsening of the somatic status of patients with coronary heart disease (CHD) and arterial hypertension (AH), as well as a predictor of quality of life decline in this category of patients.

The aim - to study the peculiarities of metabolic, psycho-autonomic disorders and their influence on the quality of life of patients with coronary artery disease with hypertension.

Materials and Methods. A prospective monocenter, double-open, randomized study in parallel groups involved 56 coronary heart disease patients: stable exertional angina II - III functional class, comorbid with hypertension (median age 59.0 (54.0; 65.0)). Patients were divided into two groups: group 1 - 34 patients in combination with anxiety-depressive disorders (ADD) and group $2-22$ patients without ADD. The quality of life study in CHD patients was conducted using the Seattle Questionnaire (SAQ) and the SF-36 questionnaire; detection of ADD - using the HADS Hospital Anxiety and Depression Scale; assessment of autonomic dysfunction - by determining the temporal and spectral parameters of heart rate variability (HRV).

Results. In patients with coronary artery disease and hypertension with ADD, more pronounced manifestations of metabolic syndrome (degree of obesity, atherogenic dyslipidemia, hyperglycemia) were observed, which had a direct correlation with the total level of anxiety and depression. Ventricular extrasystoles, significantly longer overall ST segment depression duration by $22.5 \%$ ( $<<0.05)$, and deeper ST segment depression by 2.14 times ( $<<0$, were more frequently reported in patients with coronary artery disease and hypertension). 05) compared with patients without $A D D$, autonomic imbalance with a decrease in overall heart rate variability, predominance of sympathetic link activity against the background of parasympathetic effects suppression. Patients with coronary artery disease with hypertension with ADD revealed a deterioration in the quality of life of patients according to the Seattle Questionnaire and the SF-36 general health questionnaire.

Conclusions. The presence of anxiety-depressive disorders in patients with coronary artery disease with hypertension is accompanied by more pronounced metabolic, ischemic disorders, autonomic imbalance and decreased quality of life of patients.

KEY WORDS: coronary heart disease; hypertension; metabolic and psycho-autonomic disorders; quality of life.

Отримано 3.08 .2019 